\title{
Use of Tactile Diagrams in Learning Science for Visually Impaired Students at Upper Primary Stage
}

\author{
Dr. Pramila Tanwar \\ Associate Professor (Chemistry) Department of Education in Science \& Mathematics, \\ NCERT, Sri Aurobindo Marg, New Delhi -110016
}

\begin{abstract}
The NCERT textbooks of Science at upper primary stage are available in Braille script not including any graphics, diagrams and activities as a result, it has been a challenge for student with visual impairment to 'create in your mind' the content specified in Braille textbooks. This challenge has been addressed by NCERT, Department of Education in Science \& Mathematics (DESM) to overcome such limitations. DESM has taken the initiative of given those tactile books for Science at the upper primary stage. It will smooth the progress of learning science for visually impaired students. NCERT developed tactile book in science in cooperation with Raised line foundation using 3D technology. In this paper, we are discussing about tactile book in science at upper primary stage.
\end{abstract}

KEYWORDS: NCERT Textbooks, Tactile Diagrams

\section{INTRODUCTION}

Special need student's face challenges like lack of experts in the field, inaccessible resources and absence of assistive technologies during learning science. This result in lacking interest in learning science concepts in classroomsespecially at upper primary stage.In inclusive classrooms, learners with and without disabilities learns jointly. In regular classrooms, general education teacher and special education teacher work mutually to meet up the needs of the learners. In this way special education learners get the support they require while they continue in a general education classroom. On the other hand, research studies have shown that children with disabilities are not getting equal opportunity as other students Teachers are not being skilled with reference to CWSN (PAC Report, 2018-19). A research study was conducted with the intention to find-out the difficulties faced by Children with Special Needs (CWSN) while performing science experiments in laboratory in higher secondary stage and to crop up with the solution for the various difficulties. The study reveals that the special need students studying in private international schools were happy with the facilities provided by the schools and being treated as any other children and they hardly find any difficulty in doing practical's. The condition was not similar in the case of student studying in government schools. The reason was lack of resources and poor infrastructural facilities. Keep this in mind NCERT take up an initiative to meet the needs of these students. They must be integrated in mainstream education for the implementation of inclusive education tactile books in science plays a major role.

NCERT had developed tactile book in science at upper primary stage for visually impaired student to make available handy versions of Graphics and diagrams. These tactile diagrams are perceived by touch. In these tactile books illustrations are in the form of diagrams, pictures with Transcribers notes to understand and comprehend easily.

A few examples of tactile representations. 
International Journal of Current Science Research and Review

ISSN: 2581-8341

Volume 04 Issue 07 July 2021

DOI: 10.47191/ijcsrr/V4-i7-18, Impact Factor: 5.825

IJCSRR @ 2021

www.ijesrr.org

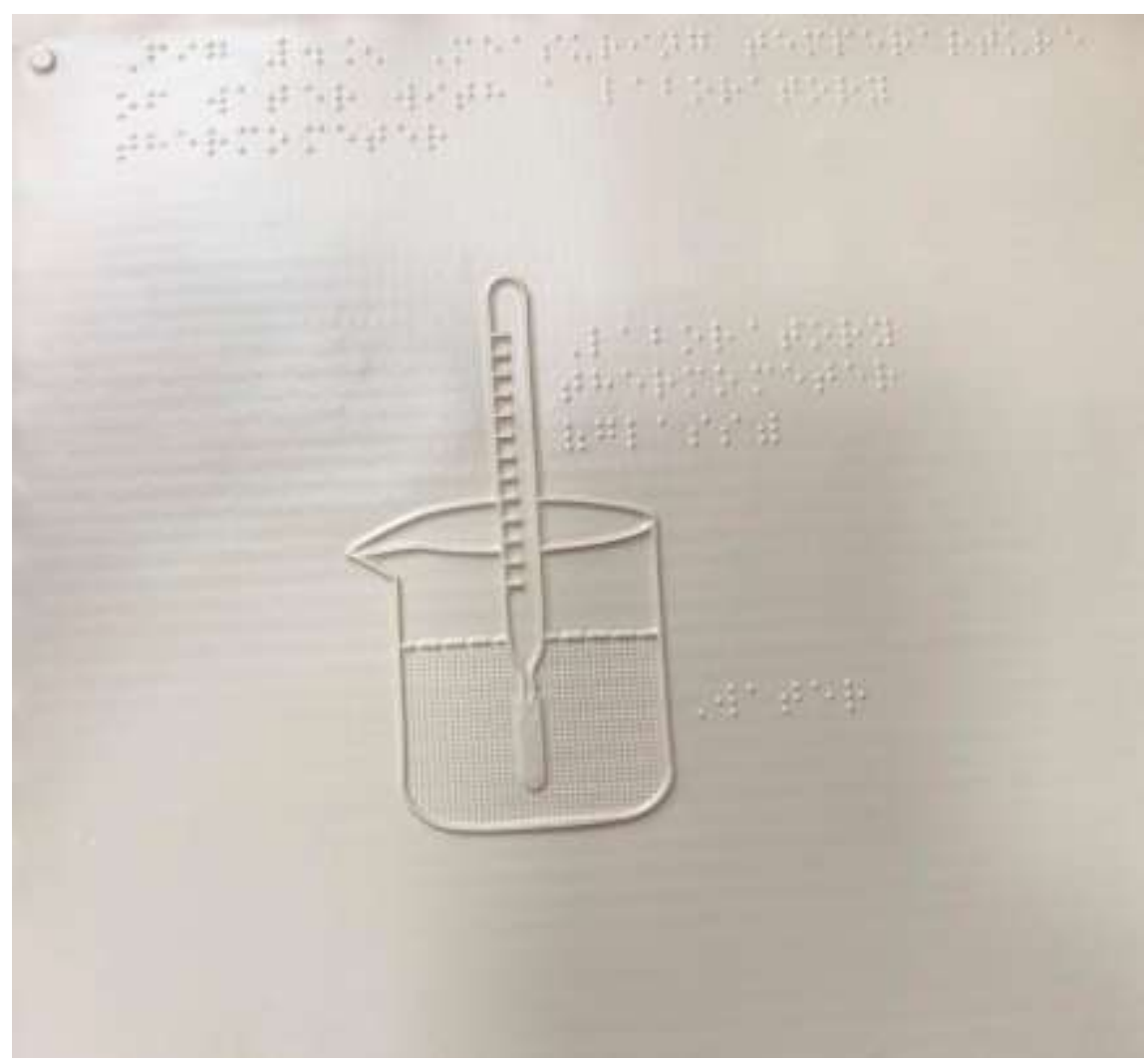

Figure 1. Laboratory Thermometer

Measuring temperature of water with a Laboratory thermometer

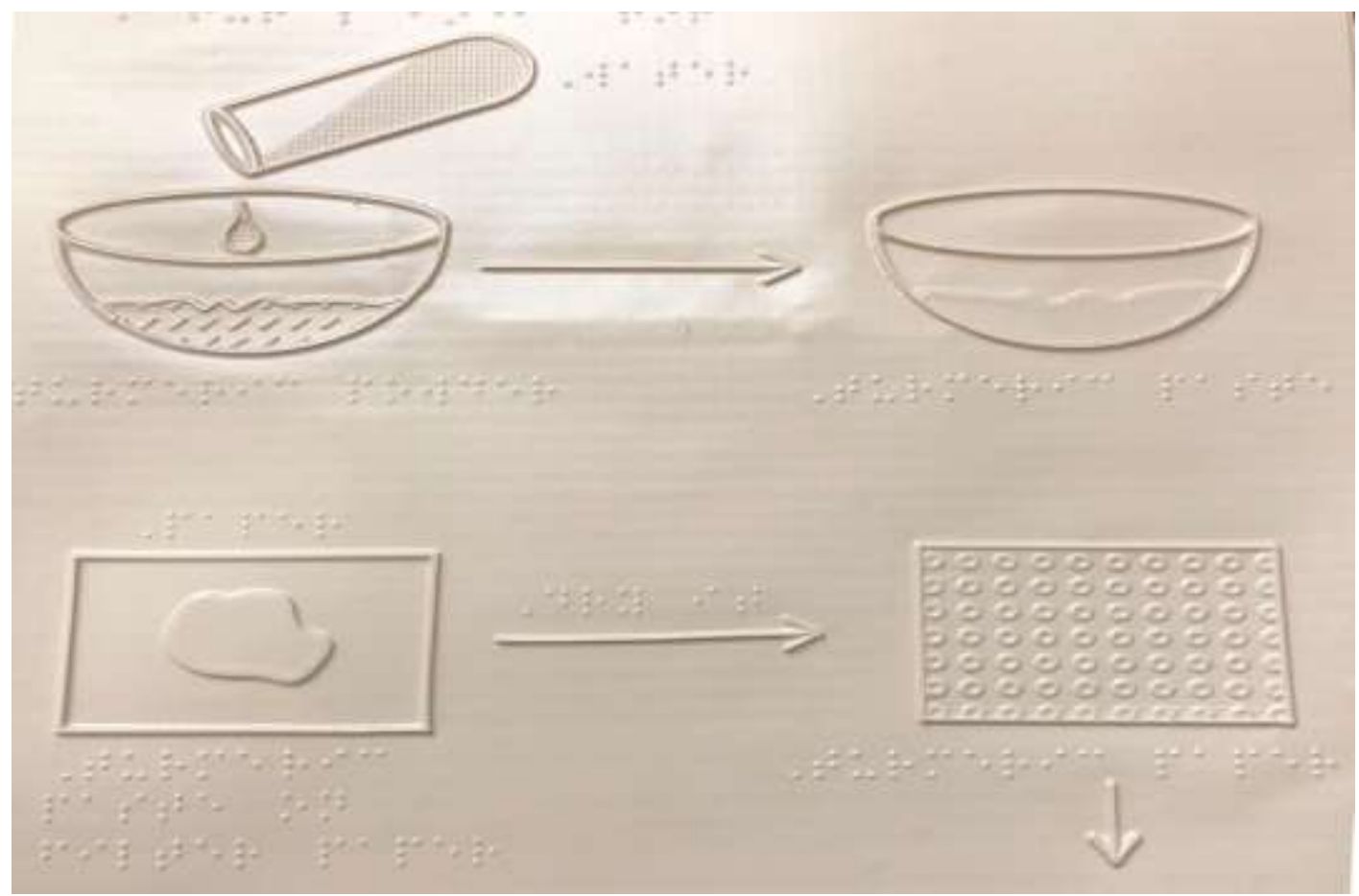


International Journal of Current Science Research and Review

ISSN: 2581-8341

Volume 04 Issue 07 July 2021

DOI: 10.47191/ijcsrr/V4-i7-18, Impact Factor: 5.825

IJCSRR @ 2021

www.ijesrr.org

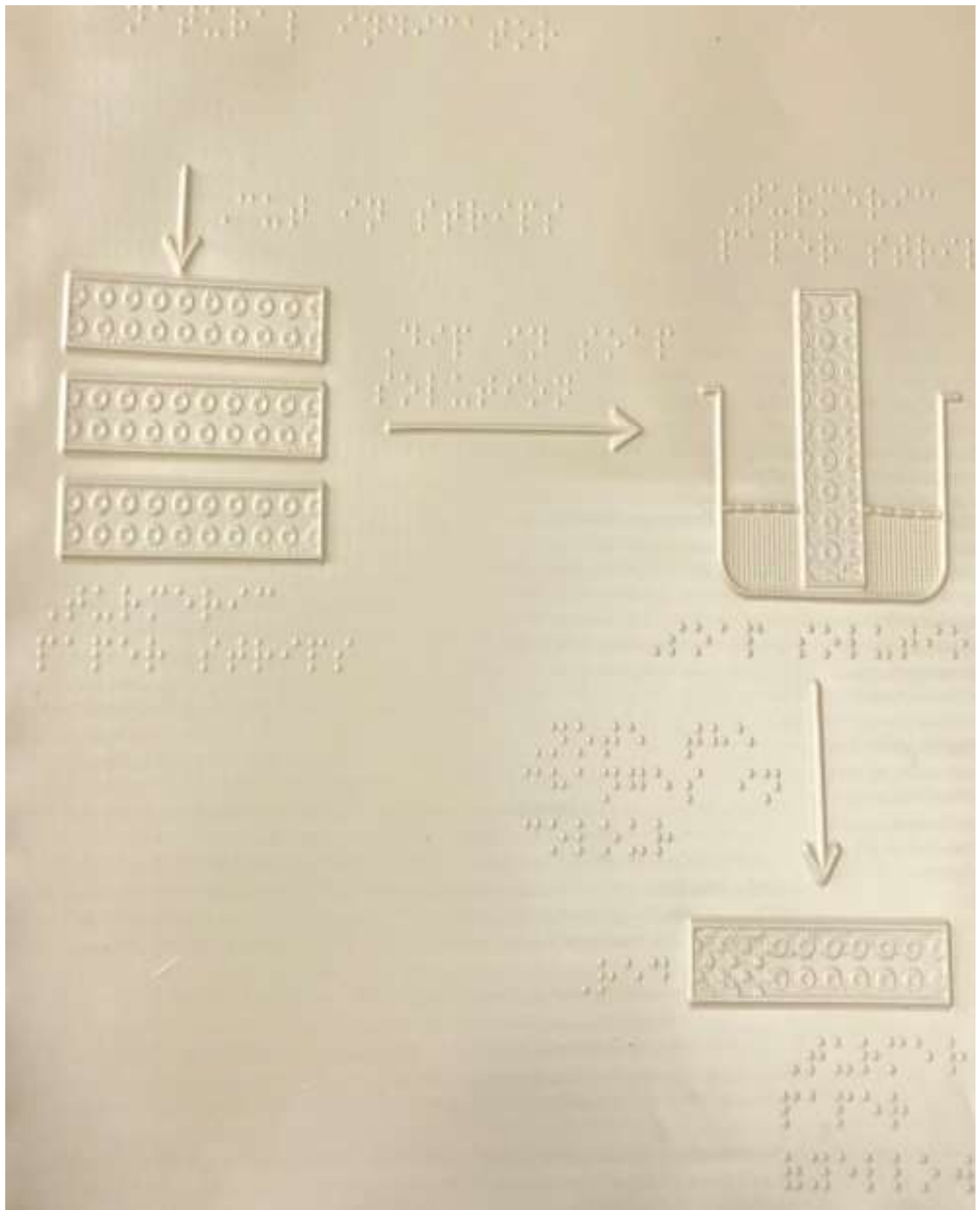

Figure 2. Turmeric - A natural indicator, the tactile diagram shows the complete process stepwise. Complete process has been divided into two. 
International Journal of Current Science Research and Review

ISSN: 2581-8341

Volume 04 Issue 07 July 2021

DOI: 10.47191/ijcsrr/V4-i7-18, Impact Factor: 5.825

IJCSRR@ 2021

www.ijesrr.org

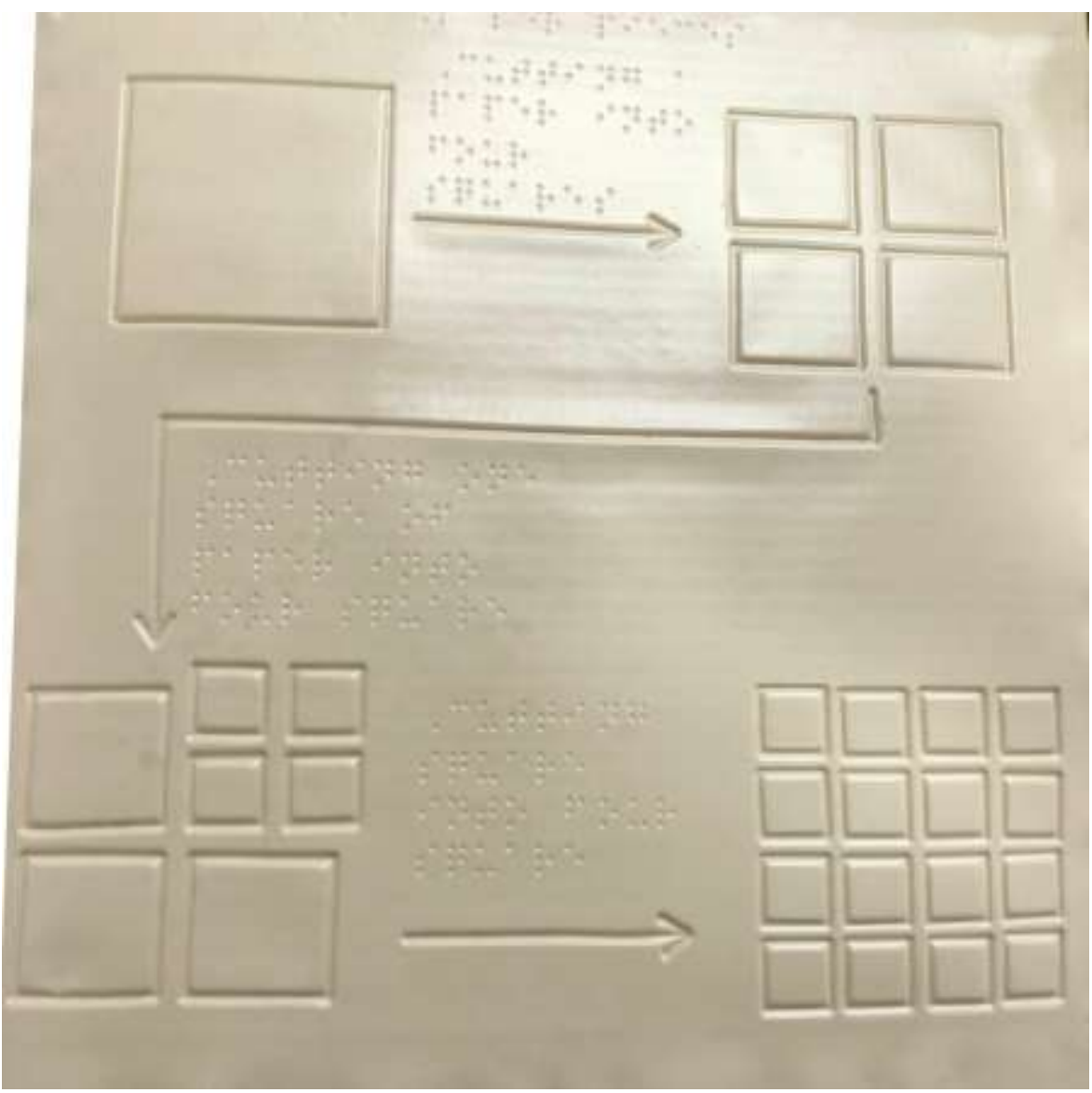

Figure 3. Paper pieces

Tactile diagram shows the complete activity stepwise

Tactile Books and Graphics...

The design cycle for tactile books are prepared in the following sequence as shown in figure 4:

\begin{tabular}{|l|l|}
\hline $\begin{array}{l}\text { Instructions } \\
\text { - Designing the illustrations and diagrams using Corel Draw in SVG } \\
\text { format }\end{array}$ \\
\hline Production & - Production of diagrams in tactile format using 3-D technology \\
\hline Feedback & - Feedback \& evaluation of tactile books by students and teachers \\
\hline
\end{tabular}

Figure 4. Design cycle for tactile graphics 


\section{International Journal of Current Science Research and Review}

ISSN: 2581-8341

Volume 04 Issue 07 July 2021

DOI: 10.47191/ijcsrr/V4-i7-18, Impact Factor: 5.825

IJCSRR @ 2021

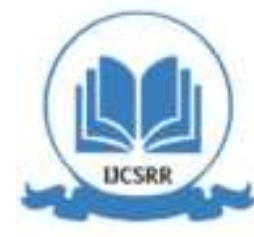

Www.ijcsrr.org

To enrich the textual information given in Braille textbooks, tactile books are introduced in science for visually impaired students. Tactile books will generate the stand of equal opportunity for all students irrespective of visual impairments. These tactile books will help visually impaired students to understand science concepts easily in a simplified manner. Tactile books are recognized to offer books which include tactile diagrams, graphics, and illustrations and provide much better experience as sighted students to children with visual impairments. Problem solving, Analysis and drawn inference ability etc are achieved easily through the availability of right resources. Tactile illustrations mainly are subject to on the texture, size and sequence of the concept.

\section{Designing of Tactile Graphics}

Braille Authority of North America and Royal National Institute for the blind, UK has developed international guidelines and standards for the incorporation, design and presentation of tactile graphics.

The following principles and guidelines were followed before creating the design of tactile graphics:

1. The first and foremost criteria are that there should be a need for tactile graphic, i.e., unnecessary graphics must be avoided.

2. The graphical representations must be presented in the tactile form.

3. The tactile graphics and Braille code needs to be same.

4. Positions of the tactile graphics should be according to the Braille code or should be placed near left margin of the books.

5. The content which is to be used should be identified and simplified so the information conveyed should be useful to the reader.

6. The information must not be given in the tactile form if it is more meaningful than the text.

7. There should always be a tactile graphic when there are questions asked about an image which cannot be answered by text.

8. Considering the content, textures, symbols and labels when planning and editing the transcription. So as to provide logical and undeviating resemblance between the graphics.

9. Documentation of the information must be done.

The images from science textbooks are redesigned using Corel draw graphics software. Corel draw is a professional vector based illustrations which edit two-dimensional images in SVG (scalable vector graphics) format. In SVG format the images can be scaled to any size while accommodating the original quality of the image. The step by step scheme for designing of tactile illustrations is shown below:

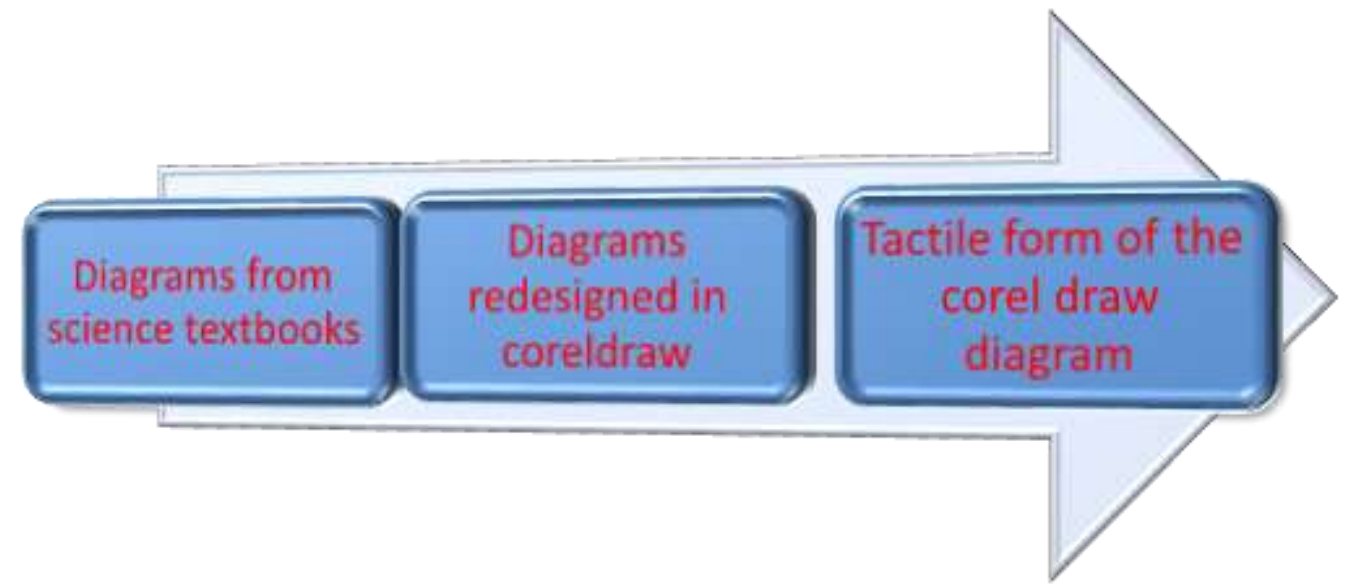

Figure 5. Procedure map of tactile image formation

Tactile diagrams are not an exact copy of a visual image to a raised diagram. To understand these tactile diagrams students need help of a trained teacher to make them understand and provide proper explanation. These books are developed keeping in mind that a visually impaired student will have same experience as sighted student in view of the fact that these books correspond through touch. A tactile diagram generally includes tactile representations of pictures, diagrams and a visually impaired student can feel these raised lines or diagrams to get necessary information.

Images from science textbooks are converted into SVG format using Corel Draw. 
International Journal of Current Science Research and Review

ISSN: 2581-8341

Volume 04 Issue 07 July 2021

DOI: 10.47191/ijcsrr/V4-i7-18, Impact Factor: 5.825

IJCSRR @ 2021

www.ijcsrr.org

Some of the examples are shown:

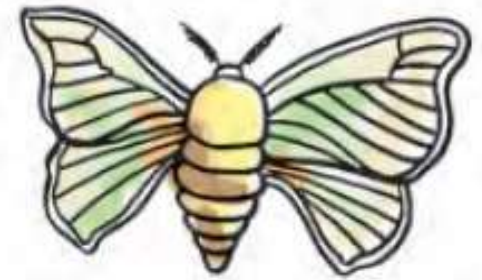

(a) Male

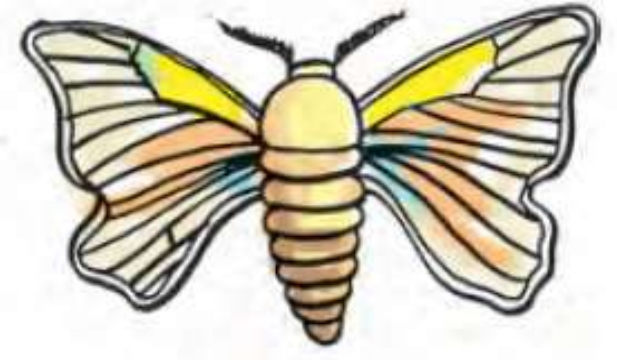

(b) Female

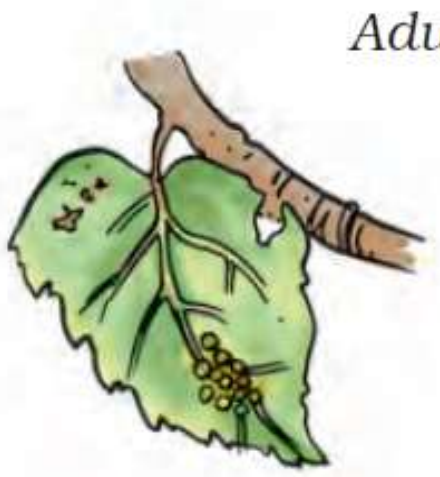

(c) Eggs on mulberry leaves

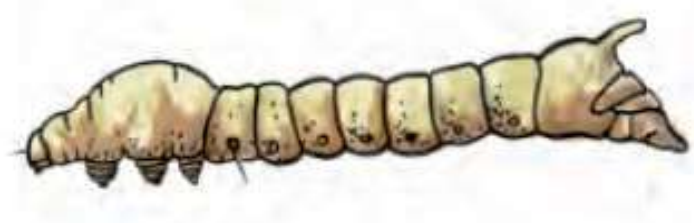

(d) Silkworm

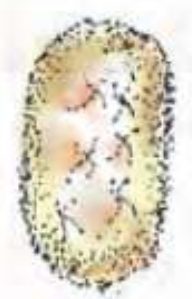

(e) Cocoon

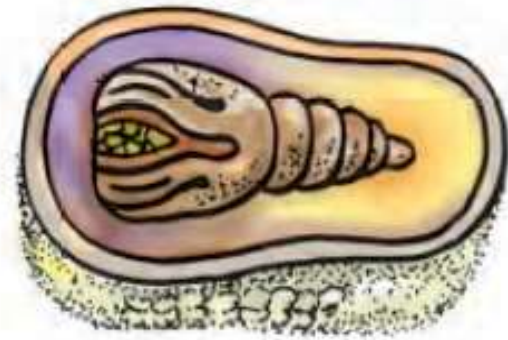

(f) Cocoon with developing moth

Figure 3.9 Image in PDF format from NCERT textbook 
International Journal of Current Science Research and Review

ISSN: 2581-8341

Volume 04 Issue 07 July 2021

DOI: 10.47191/ijesrr/V4-i7-18, Impact Factor: 5.825

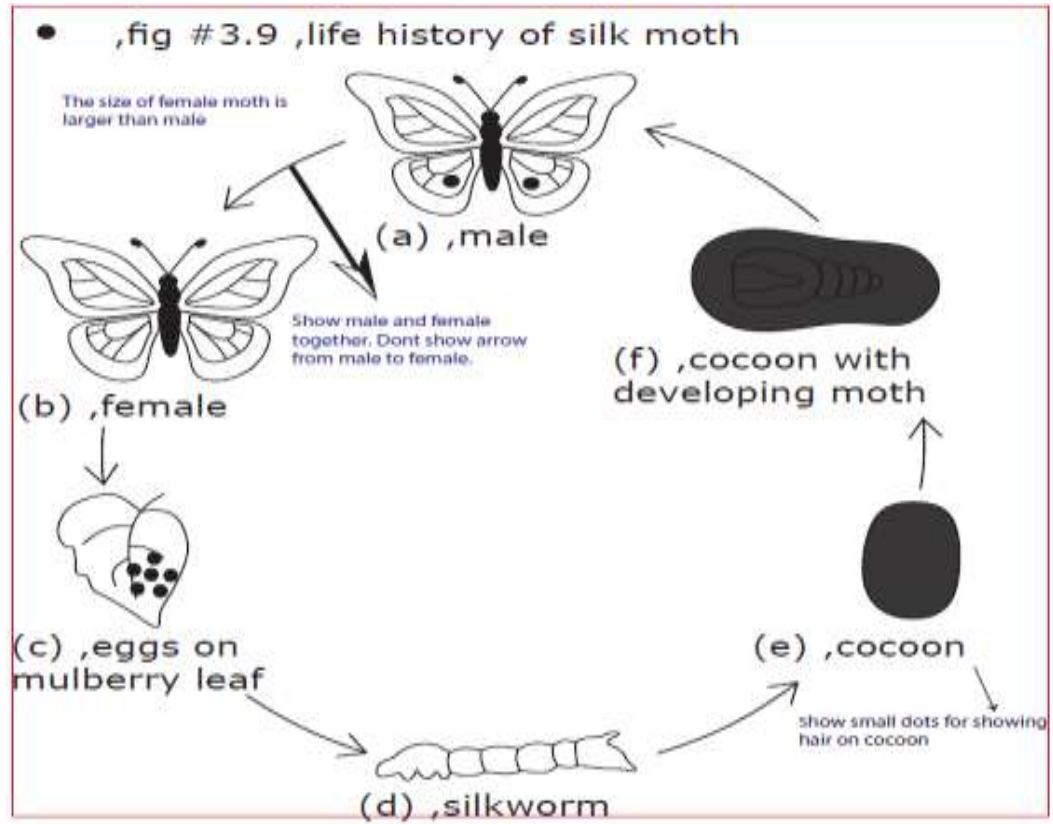

Figure 3.9 Image in SVG format

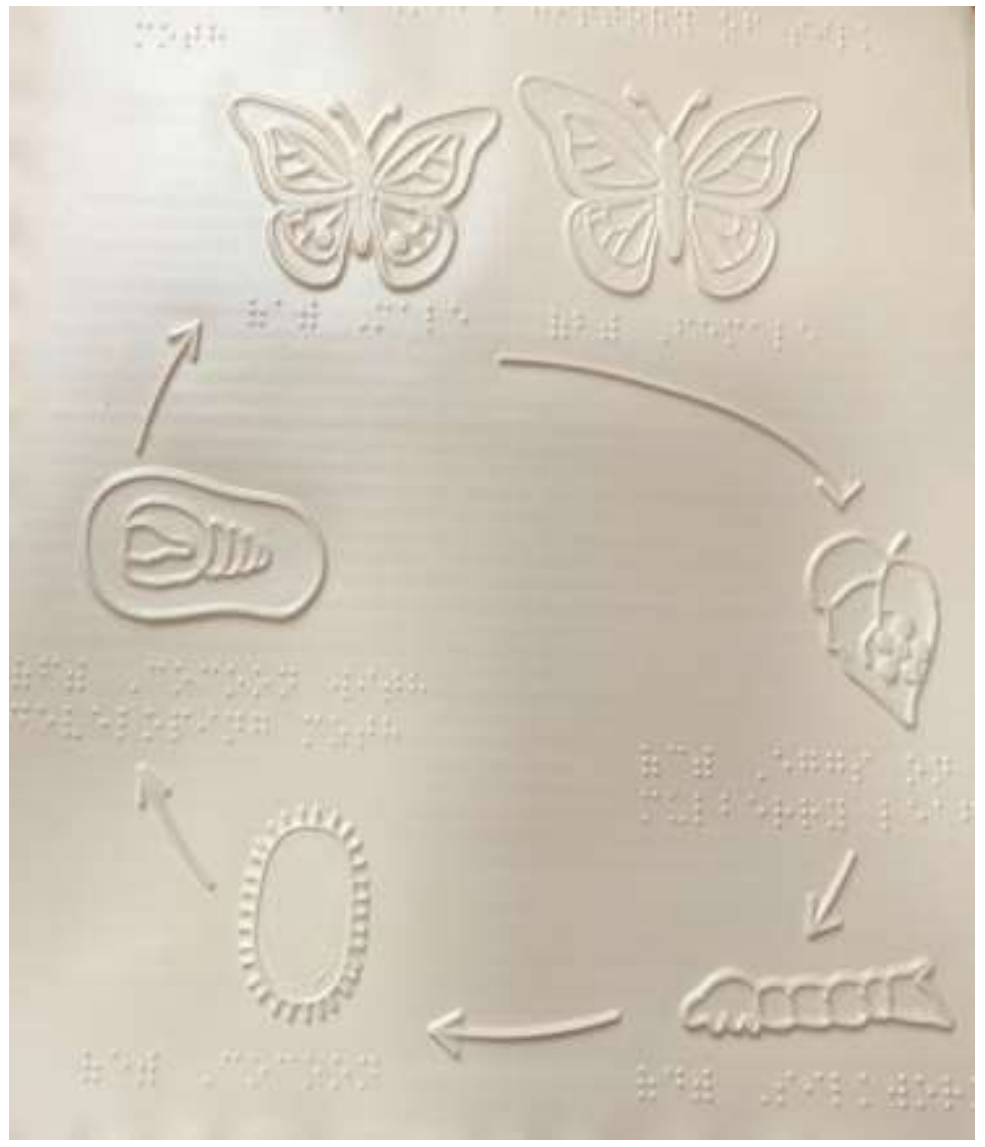

Figure 3.9 Image in Tactile Form- life history of silk moth 


\section{International Journal of Current Science Research and Review}

ISSN: 2581-8341

Volume 04 Issue 07 July 2021

DOI: 10.47191/ijesrr/V4-i7-18, Impact Factor: 5.825

IJCSRR@ 2021

www.ijcsrr.org

Second example:
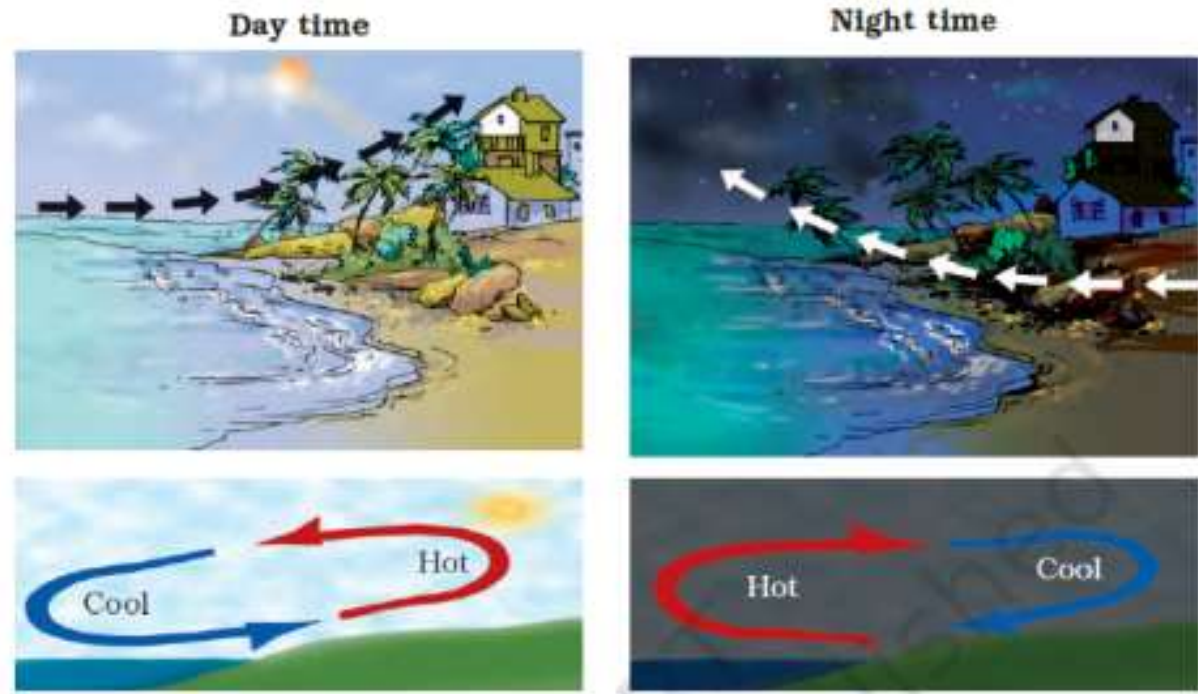

Figure 4.11 Land breeze and sea breeze (image in PDF format)

- $\quad$,fig \#4.11, land breeze and sea breeze
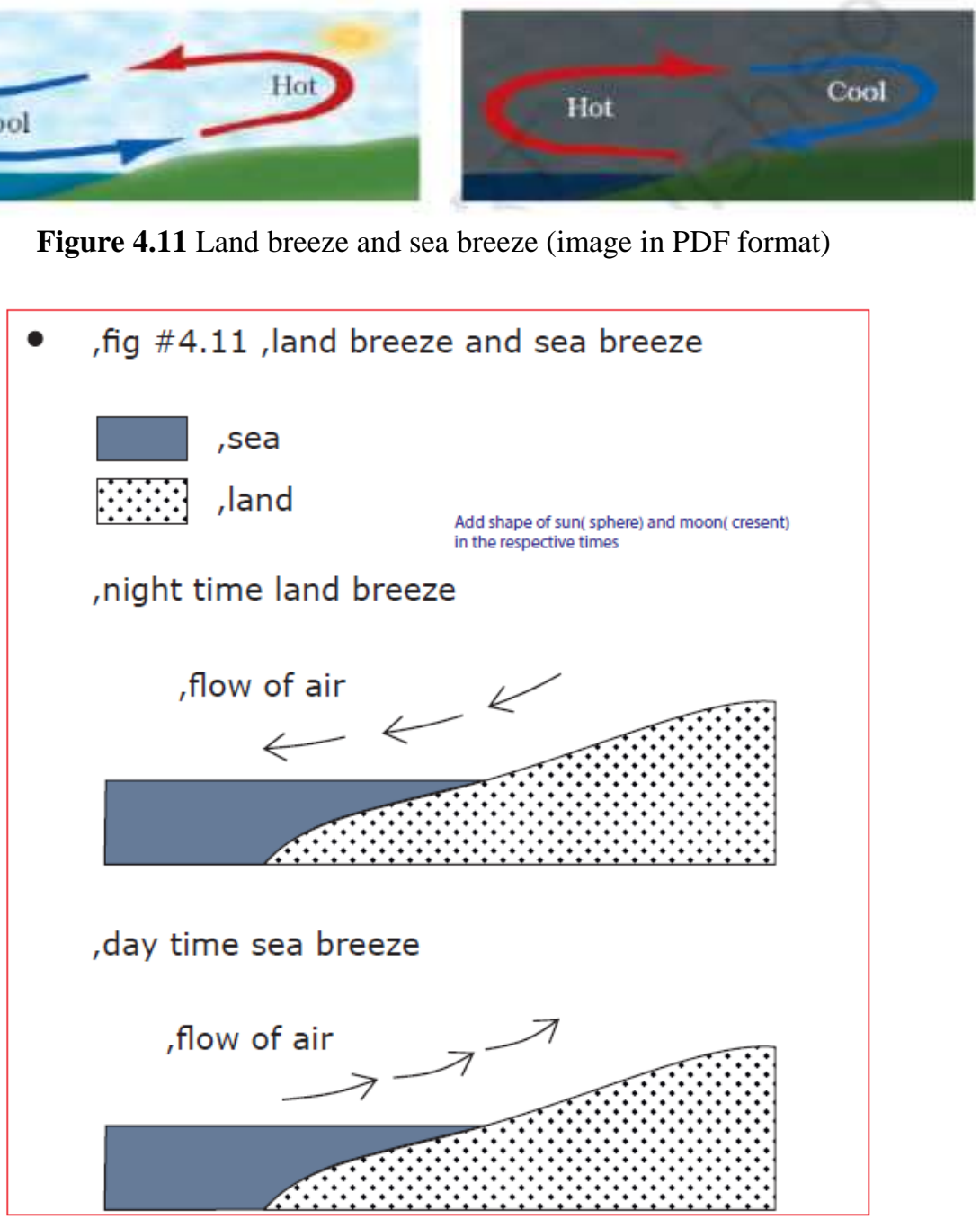

Figure 4.11 Land breeze and sea breeze Image in SVG form 


\section{International Journal of Current Science Research and Review}

ISSN: 2581-8341

Volume 04 Issue 07 July 2021

DOI: 10.47191/ijcsrr/V4-i7-18, Impact Factor: 5.825

IJCSRR @ 2021

www.ijjcsrr.org

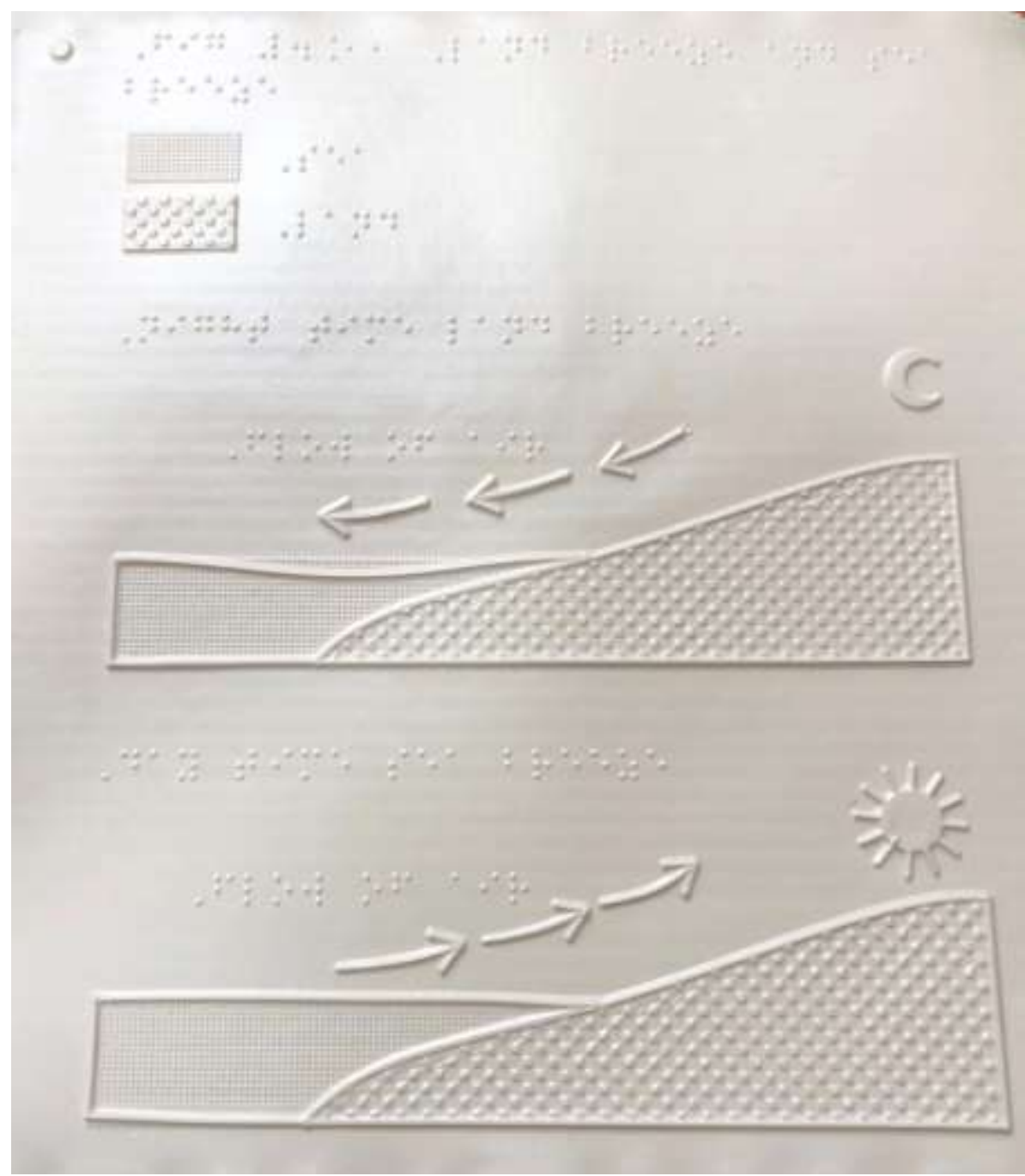

Figure 4.11 Land breeze and sea breeze Image in Tactile format

Corel draw can open and edit original layout and design tactile diagrams can be created on thermoforming sheets easily, which leads to low cost and make this procedure cost effective. The 3D technology is used to emboss the essential diagrams and pictures.

The main objective in making these embossed diagrams is to make it easy to feel and understand for visually impaired students.

\section{CONCLUSION}

Science Textbooks are offered in Braille arrangement for visually impaired students but missing the pictorial information and diagrams, so to restrain this Tactile Books in science were developed. The aim and objectives of tactile books and diagrams is to create equal opportunities for students with visually impairments. Tactile books are available along with a transcribers' note which would to understand the diagrams easily. Mostly teachers and students both find interest in using tactile books in science.

\section{REFERENCES}

1. Accessibility of Science Laboratories for the Children with Special Needs (CWSN) at Higher Secondary Stage, PAC Report, 2017-2018, NCERT.

2. Stanford Encyclopaedia of Philosophy. https://palto.stanford.edu/entries/diagrams/

3. BANA guidelines and standards for tactile graphics. https://www.brailleauthority.org/tg/

4. Science textbooks http://www.ncert.nic.in/ 


\section{International Journal of Current Science Research and Review}

ISSN: 2581-8341

Volume 04 Issue 07 July 2021

DOI: 10.47191/ijcsrr/V4-i7-18, Impact Factor: 5.825

IJCSRR @ 2021

www.ijjesrr.org

5. CorelDraw https://www.coreldraw.com/en/

6. Production http://assistech.iitd.ernet.in/

7. Sue Hanaeur, 1968

Cite this Article: Dr. Pramila Tanwar (2021). Use of Tactile Diagrams in Learning Science for Visually Impaired Students at Upper Primary Stage. International Journal of Current Science Research and Review, 4(7), 745-754 